\title{
MODERN FLUORESCENT TECHNIQUES TO INVESTIGATE THE MECHANISMS OF LYMPHOCYTE ACTIVATION
}

\author{
G. A. LIUBCHENKO' ${ }^{1}$, R. M. MORIEV ${ }^{2}$, L. S. KHOLODNA ${ }^{1}$ \\ ${ }^{1}$ Taras Shevchenko National University of Kyiv, Ukraine; \\ ${ }^{2}$ Bogomoletz Institute of Physiology, National Academy of Sciences of Ukraine, Kyiv; \\ e-mail: gannalb@yahoo.com
}

Fluorescent proteins are promising tools for studying intracellular signaling processes in lymphocytes. This brief review summarizes fluorescence-based imaging techniques developed in recent years and discusses new methodological advances, such as fluorescent photoswitches, fluorescence recovery after photobleaching (FRAP), fluorescent resonance energy transfer (FRET), fluorescence lifetime imaging microscopy (FLIM), photoactivated localization microscopy (PALM), stochastic optical reconstruction microscopy (STORM), stimulated emission depletion (STED), total internal reflection fluorescence (TIRF) and other techiques. This survey also highlights recent advances in vitro imaging of live tissues, novel applications of flow cytometry with genetically modified fluorescent proteins, and future prospects for the development of new immunological test systems based on fluorescent protein technology.

Key word s: lymphocyte activation, assays, fluorescent proteins, fuorescence techniques.

$\mathrm{T}$ he immune cell activation is a complex and multistage process. Regulation of molecular cascades leading to specific immune responses involves multiple molecular components with the lymphocyte as a primary regulatory unit of the immune system. Transient synaptic contacts with different types of immune cells, exposure to soluble cytokines, chemokines, antigens and antigen/ antibody complexes determine the lymphocyte response. Studies of the complex network of signaling systems in immune cells necessitated the development of novel research methodologies applicable to living cells, tissues and organisms. Knowledge gained from the studies of lymphocyte activation mechanisms is important in our understanding of key processes of protective immunity induction, anti-tumor immunity, vaccine development, regulation of autoimmune processes.

Molecular immunology is a rapidly developing area of modern biomedicine. This review discusses novel non-invasive research approaches based on fluorescent proteins that are applicable to the study of different stages of lymphocyte activation.

Research methods with using fluorescent proteins to study signaling processes have several unique features. First, the fluorescent proteins-based tag is introduced into the native genetic apparatus of cell to produce an enhanced fluorescence signal by certain proteins and their complexes without fundamental changes of physiologic processes in a cell. Studies can be conducted not only in vitro, but also in vivo using two photon and infrared microscopy techniques. Introduction of one or two genetically encoded tags into the structure of enzymes/ signaling proteins enables the tracking of changes in their activity, localization and interactions with other molecular complexes within the cell at a single molecule resolution in real time that cannot be achieved with other methods. Fluorescent proteins are well suited for studies of intermolecular interactions that occur in intact living cells and tissues that otherwise would have been destroyed during fixation and staining. Also, the use of genetically encoded proteins enables simultaneous expression of many genes of interest in the cell, and in the case of "fluorescent timers" - to determine how their expression changes with time. Fluorescent proteins have been adapted to many modern methods of microscopy and flow cytometry, nanotechnological approaches, and in the past decade have been actively used in studies of activation processes in lymphocytes.

\section{Fluorescent proteins are powerful research tools}

The history of genetically encoded fluorescent proteins (FP) began with the discovery of green 
fluorescent protein (GFP) from the jellyfish body bioluminescent Aeqorea victoria in the early 1960's [1].

FP chromophore located in the center of the protein and in vivo FP is formed as a result of chemical reaction between side radicals of residues of three consecutive amino acids; the first of them varies, and the second and third ones are tyrosine and glycine. FP have significant advantages over other fluorescent tags: high chemical resistance in the body, lack of the need to use complex staining procedures, possible use both in long-term experiments in vitro and in vivo, minimal invasiveness; the formation of fusion proteins provides specific labeling of the target protein [2].

Genetically modified FPs have been created which do not cause the formation of toxic aggregates characteristic of FP. Another problem with the use of FP (the inside vectorial recombination in expression systems with FP) has been solved by standard methods, for example, by synonymous substitution of nucleotide in FP genes [1-3].

The most advanced FP technology achievements are modern FP-photoswitch and fluorescent timers with emission in the red and close-to-infrared part of light spectrum. FP called "fluorescent timers" change the wavelength of emission with time as a result of the slow fluorophore maturation process. This allows obtaining data concerning the distribution of the proteins expression intensity in time. For example, FP-timer - Kusabira Green Orange - completely changes the green fluorescence to orange one during about 10 hours. FP-photoswitches can be activated under certain wavelength, thus changing the intensity or wavelength emission. The above photoswitches may be divided into 3 groups : PAmCherrys and PATagRFP with irreversible transition from non-fluorescent to fluorescent state under violet light; Dendra2, mEos2, mKikGR, mIrisFP with irreversible transition from green to red fluorescence under violet light, and rsTagRFP - FP which, when maturing, move from non-fluorescent form to red fluorescent one, but under yellow light it is extinguished and under blue light returns to fluorescent state. FPphotoswitches permit tracking the movement of signaling molecules and formation of supramolecular complexes in any part of the cell. It is necessary to selectively enable or disable FP by laser beam in a particular area of the cell and track changes which take place in this area. An alternative to the use of FP is the use of antibodies or other molecules capa- ble of binding to biological targets; the molecules are labeled with synthetic organic dyes or quantum labels - fluorescent nanocrystals. Organic fluorescent dyes are usually brighter, easy-to-apply compared to FP. Photoactivation dyes, e.g. EOS, are also among these dyes. The great number of effective probes for determining the concentration of calcium ions and other ions has been developed to the level of commercially available tools of research. Most optical filters for fluorescence microscopy were designed specifically for synthetic labels. Quantum tags have almost ideal properties to be used in fluorescence microscopy or other biological techniques: resistance to photodestruction, brightness, the number of colors available, stable fluorescence in different environments and a wide range of excitation. However, the known quantum labels cannot be photoactivated and change their fluorescence spectrum with time. Therefore, fluorescent timers are created only on the basis of FP. Both organic dyes and quantum labels may be used for experiments with resonance transfer of fluorescence energy. The main disadvantage of methods based on synthetic dyes and quantum labels concerns the delivery of the label into the cell. Since these probes are used as synthetic conjugates with specific antibodies or, for example, receptor proteins, they cannot be genetically encoded and their delivery through the plasma membrane into the cytosol and other intracellular compartments of living cells is technically very difficult. Such probes can be effectively used to study fixed preparations of cells and tissues or structural elements of the cell plasma membrane in vivo. Therefore, the best tools for the study of fast biological processes, including those of intermolecular interactions and gene expression, are genetically encoded FPs, which, in addition, have the lowest toxicity and phototoxicity.

The problem of genetically encoded FP is the preparatory stage of introduction of genetic structures in the cell or the entire organism. As this stage is overcome researchers obtain a convenient and effective tool [1-4].

\section{Activation of immune cells is key immune process that requires a large-scale introduction of molecular research methods}

Activation of immune cells is a key link in the formation of specific immunity. All intracellular biological processes that start from the interaction of antigen (ligand) with lymphocyte receptors and lead to the synthesis of cytokines are called activa- 
tion of lymphocytes. This process causes the launch of specific effector mechanisms of the immune response. Activation of lymphocytes leads to their proliferation, differentiation, development of memory cell subpopulations. Creation of test systems for the study of lymphocyte activation is both of theoretical and practical importance in various fields of biology and biologic medicine. The phenomenon of blastcell transformation in vitro was used in the classical test of lymphocyte activation. This phenomenon can be quantitatively estimated with the use of microscopy, chromogenic MTT-test or with the inclusion of radioactive $\left[{ }^{3} \mathrm{H}\right]$-thymidine tag into DNA in the culture of stimulated lymphocytes. These methods are labor-intensive, prolonged, but do not allow one to track signaling mechanisms of activation, which are distinguished depending on the type of mitogen, do not indicate the direction of differentiation, apoptosis rate and physiological state of lymphocytes before and after stimulation [5].

Activation of lymphocytes begins with the interaction of extracellular receptors and co-stimulative molecules of plasma membrane lymphocytes with antigen. If antigen is bound on the cell surface, the immune synapse (IS) is formed - the receptormediated contact of lymphocyte plasma membrane or natural killer cell membrane with target cells or antigen-presenting membrane. Formation of IS is the first step in signal transduction in immune cells. It is commonly supposed that the key to activate $\mathrm{T}$ cells is antigen that increased phosphorylation of tyrosine residues of immunoreceptor tyrosine-based activation motif (ITAM) in TCR subunits under the effect of family kinases Src: Lck and Fyn. The increased local concentration of kinases and their substrates likely results in oligomerization of different subunits in the process of formation of the immune synapse and the displacement of protein tyrosine phosphatases (TPF) and kinase Csk, which phosphorylates Lck, deactivating it [6] Co-stimulative molecules also take part in formation of IS, for example, such as membrane protein CD80 of antigen presenting cells and the corresponding T-cell receptor CD28, as well as the adhesion protein ICAM. Chemokine and cytokine receptors, which are not included in IS but are not of first importance in activation, also take part in the signal modulation. The intracellular messengers, which function in the cytosol in this process, are activated forms of various kinases, inositol triphosphate, diacylglycerol, calcium ions and other signaling proteins, including G- proteins. A cascade of guanine-nucleotide-binding protein Ras with molecular weight of $21 \mathrm{kDa}$ is one of the TCR signaling cascades. A number of intermediates operate between this signaling protein and TCR; they form a multiprotein complex. This leads to GTP substitution for HDF bound on the surface of the molecule Ras. The substitution of nucleotides activates Ras, which activates MAP kinase cascade RFP-MEK-ERK [7, 8].

The critical role of other intracellular signaling cascades, such as p38 MAP-kinase, c-Jun NH2terminal kinase (JNK) $[9,10]$ was also established. Another critical signaling cascade is the synthesis of calcium channel activators and inositol-triphosphate as a result of hydrolytic splitting of phosphatidylinositol diphosphate by phospholipase C, which leads to an increase in cytosolic calcium concentration [11-17].

The activation alarm reaches chromatin at the expense of transport of signaling molecules to the cell nucleus and provides persistent changes of gene expression of adhesion proteins, receptors, cytokines and chemokines. These molecules include proteins, Jak and STAT, proteins of NF- $\kappa$ B family, the above proximal signaling proteins of MAP- kinase pathways of ERK, p38, c-Jun, which are activated when phosphorylated, as well as NFAT - the factor that is activated by di-phosphorylation by calcineurin phosphatase with increasing concentrations of cytosolic calcium. The role of the above messengers was studied by the methods of genetic knockout, action of low-molecular enzyme inhibitors, histological and cytological studies, classical immunologic tests, Western and Southern blotting. These methods make it possible to establish the effects of recent activation processes, but do not allow us to establish which messenger is involved in the early stages of activation and features of its localization and dynamics in the cell. A number of studies have shown that even after 4 hours of activation there appear all molecular genetic markers that indicate the intensity of antigenic stimulus and subsequent differentiation of lymphocytes. The main markers of lymphocyte differentiation are activation antigens CD69, CD71 (transferrin receptor), CD25 and DR antigen histocompatibility complex. To investigate these subtle processes the multiparameter monitoring of signaling cascades in real time under conditions maximum close to native is required. The methods using genetically encoded fluorescent proteins that allow multicolor labeling, minimal impact on the studied 
processes and the possibility of using in vivo, are promising to study the activation of lymphocytes [18-22].

\section{Investigation of lymphocyte activation in vitro}

The first lymphocyte immunofluorescence inversigations have shown that co-receptors CD4 and CD8 are concentrated in contact with T-lymphocytes and antigen presenting cells (APC). It has been shown that TCR and molecules of PKC $\theta$ focus in the center of IS. Adhesion molecules - ICAM and related ones form concentric circles around the center, and phosphatase CD45 is concentrated in the periphery of IS. Using genetically encoded FP it has been shown that PKC $\eta$ is also involved in IS during activation of $\mathrm{T}$ lymphocytes and structures similar to IS, with participation of TCR and CAM1 can also be created by the interaction of microbial pathogenicity factors, e.g., Staphylococcus aureus with surface of B-lymphocytes [15, 23, 24].

To study protein dynamics we used the method of fluorescence recovery after photobleaching (FRAP). It has been demonstrated by FRAP, that different components of IS have different mobility, and TCR and some other components of IS are actively transported to the center of IS and form endocitosis bubbles. These processes are elements of fine regulation of lymphocyte activation. To study the interaction of molecules of IS the genetically encoded probes based on FP were used and a phenomenon of resonance transfer of fluorescence energy between two different FP within individual proteins that form a complex (FRET - fluorescent resonance energy transfer) and measuring the time of donor fluorescence decay - FLIM (fluorescence lifetime imaging microscopy) to determine the degree of interaction between FP and associated proteins in the complex. Using FRET the authors have established the details of not completely studied signaling mechanism BCR and TCR: BCR aggregate under the action of antigen and cytoplasmic portion of CD3 $\varepsilon$ - TCR component, interacts closely with the inner surface of the cytoplasmic membrane. It is determined that MHC molecules form much more stable complexes with TCR when located in the plasma membrane of cells, rather than in solution. It was also determined that signals to antigens that induce a productive immune response of $\mathrm{T}$ cells, are accompanied by a slow, but continuous involvement of fluorescently labeled coreceptor $\mathrm{CD} 8+$ to the synapse and its interactions with fluorescently labeled CD3 (Fig. 1). Instead, while those antigens that cause immunological tolerance, cause rapid and short-term co-receptor involvement [25-28].

To quantify the molecule mobility within the supramolecular complex the method of fluorescence polarization is also used. Application of polarization method with synthetic fluorescent dyes and FP revealed the fact that the weak activation signals through FceR1 (Fragment crystalline $\varepsilon$ receptor 1) can take place without immobilizing these receptors in a cluster on plasmatic membrane. In these studies, FP can fully replace synthetic dyes. The authors have demonstrated with the help of FRET rapid involvement to IS (at the start of activation) of signaling proteins labeled using genetically encoded FP: ZAP70, PLC $\gamma 1$ phosphatase, membrane adapter protein LAT, ubiquitin ligase and cytosolic adapter protein $\mathrm{CBL}$, regulator of formation of G-protein cytoskeleton VAV1, adapter proteins SLP76, NCK. It was also proved using FP and FRET, that stromal protein STIM (stromal interaction molecule) interacts with membrane calcium channel ORAI, which provides signaling via calcium ions during the activation of lymphocytes. Using genetically encoded lymphocyte activation sensors based on ZAP-70 and FP, it has been shown that this kinase is activated both in the undermembrane complex and throughout the whole cytosol volume. Nuclear localization of critical factor of activation of T lymphocytes - NFAT [24, 27, 29] was demonstrated using FP.

\section{The use of high-resolution fluorescence microscopy techniques to study the activation of lymphocytes}

Previously, it was postulated that it is impossible to overcome the diffraction limit of microscopy. But over the last few years a number of techniques have been developed which allow detecting individual molecules and determining their exact location basing on the computer data processing. These methods are PALM (photoactivated localization microscopy) in other versions, this approach was called FPALM (fluorescence photoactivated localization) and STORM (stochastic optical reconstruction microscopy), sptPALM (single-particle-tracking PALM). All the above methods of microscopy require labeling of target proteins using fluorescent labels capable of photoactivation. High resolution of all these methods is achieved by activation of small portions of molecules with a special laser, 


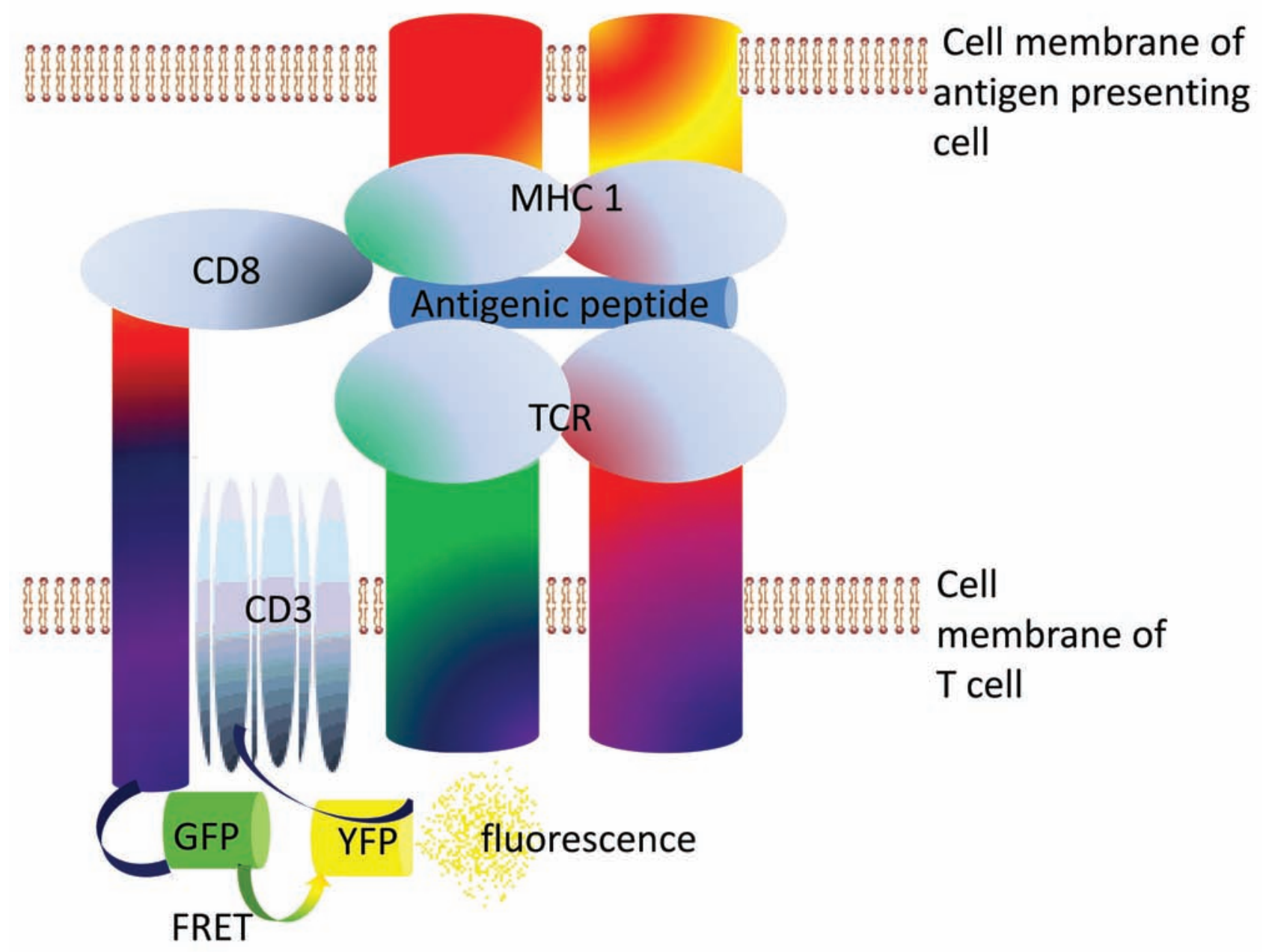

Fig. 1. Control of TCR interaction with antigen under formation of immune synapse. Tight convergence of coreceptors CD8 and CD3 labeled accordingly in green and yellow FP leads to fluorescence energy transfer and substitution of green fuorescence by yellow one

so that each molecule can be identified separately. A number of other methods has been developed; their principle of increasing the resolution is based on illumination of certain narrow areas of the subject: STED (stimulated emission depletion), GSD (ground-state depletion) and SSIM (saturated structured illumination microscopy), FCS (fluorescence correlation spectroscopy) and FCCS (fluorescence cross-correlation spectroscopy). One more approach to increase the resolution - the selection of a thin layer of the subject under the lens in the direction of the optical axis - TIRF (total internal reflection fluorescence), which reached a significant resolution on the axis Z. The first example of the observation of individual molecules in the process of performance of their functions is to study the fusion protein E-cadherin and GFP by TIRF- microscopy. Observation of two chimeric membrane proteins in vitro using TIRF-microscopy allows you to establish the behavior of these proteins in living cells and their co-localization, complex formation in PALM mode. It is important that individual fluorescent molecules are continuously observed in the field of view and these data are particularly valuable for understanding the mechanisms of proteins involvement into complexes. The proteins Dendra, Dendra2, tandem option EosFP (tdEosFP), enhanced mEos2, which, when activated, move from bright green to red fluorescence, are effective FP-photoswitches for FRET and PALM. Recently the IS image of natural killer cell interaction with target cell was obtained using SIM-microscopy. It appeared that proteins NKG2D, Vav1 and Grb2 form a typical ring in the supramolecular complex of integrated circuits, and the movement of cytotoxic granules outside the cell provides the actin net. Using the PALM method it was found 
that there were intermolecular forces which "anchored" protein LAT in T lymphocyte and prevent the adhesion molecules ICAM1 from penetrating from the peripheral areas of the synapse to the central area. It was found in the studies with the use of FP in PALM with TIRF and PALM in combination with confocal microscopy that TCR and adaptive protein LAT form small conglomerates in unstimulated $\mathrm{T}$ lymphocytes; these conglomerates aggregate into large complexes during activation. Their interaction during activation was confirmed with the help of FCCS [30-38].

\section{Combined use of nanomaterials and FP in vitro}

Nanotechnology in combination with FP are based on the latest research strategy in lymphocyte activation processes. Nanochasing was used to induce strictly localized activation stimuli on lymphocytes and mastocytes. Artificial membranes were positioned on nanochasing surface. It was first shown that ZAP-70 and cytoskeleton proteins: actin, paxillin and vinculin form a complex with the aggregated Fc-receptors of T-lymphocytes in the process of interaction of these receptors with the submicroscopic round areas of antibodies bound on a hard surface (Fig. 2). In these experiments all investigated proteins of living cells were labeled with fluorescent proteins. Circulation of endosomes with secretory granules labeled with continuous protein
CD63-GFP around these areas was first shown as well. In other experiments the artificial membranes were used which contained MHC, ICAM-1 and LFA-1 ligands. The artificial membranes were positioned on a nanochased grid, which limited the movement of molecules with its grid. In experiments with the use of membranes with different turnover the need for aggregation of molecules of GFPlabeled kinase Zap-70 to activate T lymphocytes was confirmed with the help of this kinase. Thus, the dynamic properties of IS components have been demonstrated using FP as localization markers and nanostructured ligands [39, 40].

\section{The use of fluorescent proteins for ex vivo and in vivo research}

Modern technologies allow optical microscopy in vivo without surgery or using minimally destructive techniques. For such purposes researchers obtain transgenic animals which carry genes of necessary fluorescence-labeled fused proteins under the control of tissue specific regulatory genetic sequences. This allows studying the prepared cells and tissues without prior transfection. Another approach - the introduction of genetically modified cells into the body. This approach is convenient in the models of transplanted tissues, for example, to study lymphocyte migration and metastases of tumor allografts. FP have been successfully used for labeling lymphocytes, dendritic cells, macrophages, viruses, bacte-

\section{Fluorescence of kinase ZAP-70 fused with FP}

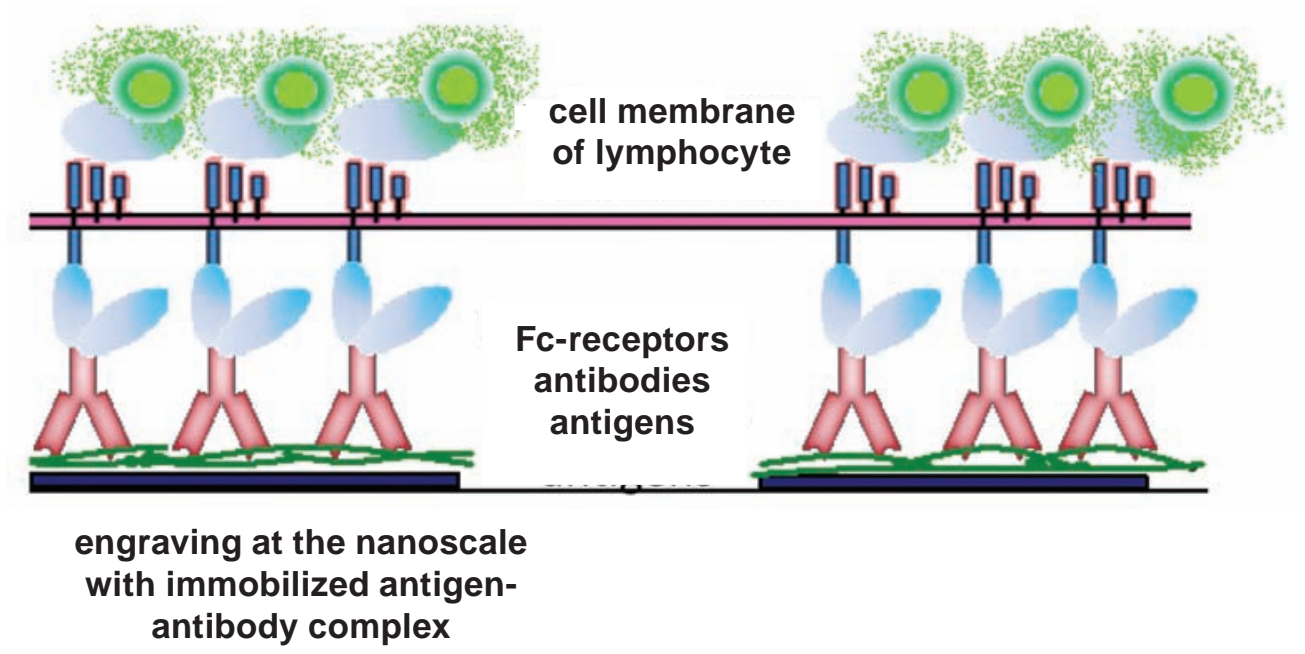

Fig. 2. Studies of spatial interaction of kinase ZAP- 70 with FC- receptor clusters on immobilized antibodies in living cells. Nanometer-sized spots with immobilized antigen-antibody complex cause clustering of both FC-receptor kinases and molecules labeled with FP domains 
ria and other pathogens and their interactions in vivo [38, 41-45].

Today, researchers are able to obtain threedimensional images or videos of individual labeled cells in vivo. Thus using the method of confocal microscopy the localization of invariant natural killer $\mathrm{T}$ cells (NKT cells) and Ito cells in mouse liver sinuses was established in vivo. GFP was used as a reporter expression of receptors CXCR6 and CX3CR1, which are markers of the corresponding cells. It was found that in response to the activation T cells (NKT cells) stop migrating through the liver sinus endothelium [46].

The most popular modern FP which are used to observe living cells through the layers of tissue in vivo and ex vivo are ECFP, mKeima, Dendra 2 Green, EGFP, YFP, Dendra2 Red, TagRFP, tdTomato, DsRed2, mCherry, mKate2, TagRFP; special attention should be given to FP of the monomer structures that prevent oligomerization artifacts: mOrange2, mRuby, mNeptune, ECFP, mKeima, EGFP, YFP, Dendra2 Red [57, 58].

Two-photon laser scanning microscopy is one of the most effective modern methods for vital microscopy. It allows one to carry out studies on multicolor labeling, to form sections by rapid automatic adjustment of the optical system and to observe intercellular interaction in the intact organism of both vertebrates and invertebrates [38, 49].

The mobility of thymocytes and their synapse formation ex vivo were first demonstrated using two-photon fluorescence microscopy with exciting laser radiation in the near infrared range. Fluorescent studies of proteins labeled using FP in vivo and ex vivo showed that CD4 + T-lymphocytes possess high mobility and the majority of IS with APC is formed for a short period of time. Two-photon microscopy was also used to study the activation and migration of tumor-specific $\mathrm{T}$ cells labeled by FP (GFP, CFP, YFP) in the animal model of melanoma in vivo [50-52].

\section{Applications of flow cytometry with genetically encoded fluorescent proteins}

FRET, multicolor labeling using FP can be effectively used for flow cytometry (PPB). There are FP convenient for PPB: with enough high-brightness and high-speed chromophore maturation. The best acceptors of FRET-probes for PPB are red FP or FP with fluorescence spectrum at the boundary of infrared spectrum, for example: ECFP and HcRed, yel- low FP mCitrine, SYFP2, Venus, LSS; mAmetrine and red mStrawberry or mCherry. These couples have FP spectra of small overlap, so, they have an advantage in sensitivity compared to FP emission in the blue and green spectrum. That is why they were used to create sensors suitable for PPB, for instance, the sensor of membrane potential and sensor of caspase-3 activity. Genetic structures providing embroidered labeling of cells in different phases of the cell cycle were also created [53, 54].

A new method for determining lymphocyte activation in vivo has been developed based on multicolor labeling of lymphocyte precursors genetically encoded with FP before transplantation to immunodeficient animals. EGFP was used as a constant marker of all lymphocytes, while HcRed was regulated by reporter CD 40L, so it was expresioned only in activated $\mathrm{T}$ lymphocytes [55].

FP provided new possibilities in the study of lymphocyte activation by CPM. Labeling with antibodies and other markers allows one to determine the concentration of biological molecules contained in cells at the time of measurement. The use of proteolysis-resistant fluorescent timer as a reporter gene allows us to assess what was the expression of a gene in a short period of time before measuring and the averaged expression activity in vivo over a period of the fluorescence intensity of mature and immature forms. Photoactivation opens an opportunity to study the prehistory of lymphocytes development in space: labeling of clearly defined areas of the body of experimental animals by the activating laser allows us to observe the migration of labeled lymphocytes from this area [56].

FP also provide the ability to track intermolecular events activated in immune cells prior to analysis by the method of biomolecular fluorescence complementation (BiMFC). Using CPM, one can analyze the activation of many signaling pathways in vivo with a high bandwidth that cannot be reached using conventional tagging [57].

\section{Development of new FP-based immunological test systems}

The next step in the research is the use of activated lymphocyte probes for studying intracellular signaling processes of the immune system in the intact living organism. Probes and markers based on FP are promising for the study of the immune system. The immune system cells are characterized by the ability to homing: migration in specific areas 
of their body after the injection. Therefore, new test system for the study of lymphocyte activation may be based on several types of model objects: genetically modified intertwine lines of lymphocytes in cell culture in vitro and as transplantants in vivo, transgenic animals and immune cells from transgenic animals [58].

The great number of probes was developed from FP to study intracellular signals has not yet been applied to the study of lymphocyte activation. For example, an important role in lymphocyte activation is played by chemokines signals and growth factors with participation of G-proteins. A number of FP-based FRET probes was developed to determine the activation of G-proteins, which play an important role in many processes, including the activation of lymphocytes.

Established on specific intracellular sensors of kinase ERK2 activity have been created following the FRET-probe principle. This approach to the construction of chimeric fluorescent protein kinase in the models of B-lymphocytes, T-lymphocytes and NK-killers makes it possible to monitor the early events in the activation of these cells under the influence of various factors in vivo [59,60].

An example of progressive embodiment of the idea of studying the lymphocyte signalling in vivo is a recently developed line of mice which express the reporter genes of lymphocytes activation and ratiometrical calcium probe to determine the calcium signals from FP. These lines were tested to study the activation and migration of lymphocytes in the experimental model of multiple sclerosis in vivo [61].

The key kinases for activation of T and B-lymphocytes are PLC $\gamma 2$ and Syk, which are translocated to the plasma membrane, and kinases ERK and p38, c-Jun, NF- $\kappa B$, mediator proteins of the effect of cytokines STAT, for activation of T-lymphocytes NFAT proteins which are translocated to the cell nucleus during signaling. Thus the FP addition to them will allow observing their activity by microscopy. The activity of other key signaling proteins: G-protein, kinase Zap, Lyn, may be monitored via appropriate FRET-sensors, since a change in their activity is not accompanied by a significant change in localization. In order to confirm the activation of lymphocyte and subpopulation types, which include the studied cells, one should also use the reporter genes under the relevant expression regulators or fusion proteins on the basis of CD3, CD4 to identify lymphocyte populations and major surface activation markers CD69, CD71 and proliferation reporter. Thus, at least 20 separate fluorescent signals are needed to monitor the activation events in individual cells. Recently, there appeared effective cassette plasmids for obtaining transgenic mammalian cells that can carry a lot of recombinant genes simultaneously. Thus there appears the prospect of a system approach with the use of multiple probes in the studies of signaling pathways of lymphocyte activation using FP. There are also first experimental microscopes, for which the number of detected FP is limited by the variety of excitation spectra and emission of available set of FP and can potentially reach several dozens. Therefore, using FP with different combinations of wavelengths of excitation and emission, methods of mathematical spectral division, combining of conventional fluorescence detection and separation of signals in time of fluorescence half-life, which is different for different proteins might theoretically detect more than 10 fluorescent signals simultaneously [62-66].

Despite the minimal invasiveness and low level artifacts with modern FP there is the need of validation and verification of the models based on them. The methods of in vitro microscopy, using the probes of kinase activity and translocation of signal FP to the plasma membrane, can be checked using antibodies to the corresponding signaling proteins and peptides phosphorylated substrates of kinase and other signaling proteins. To obtain relevant information it is necessary to apply the method of instant freezing of the whole organism followed by the preparation of frozen products and histochemical studies. MALDI-microscopy, in which the mass spetrometry is used to identify a variety of molecules "knocked out" of the drug under the effect of laser, is the most modern method that replaces the standard histochemistry. It is possible to check intermolecular interactions in the cell culture using the proteomic method of immunoaffinity chromatography with the help of mass spectrometry analysis. In this method molecular complexes bind to antibodies through a chromatographic column and their composition is analyzed by mass spectrometric detector. It should be noted that due to the lowest invasive techniques with FP, compared with other methods, the obtained results cannot be confirmed in all cases. In many cases it is expedient to check the obtained results using the above mentined quantum labels and synthetic dyes [67-69].

The in vitro research is important for experiments in which the immune cells have to act on spe- 
cific signaling mechanisms of lymphocyte activation. Great hopes may be set on the above genetic constructs for CPM that could be used both in vitro, and in vivo.

The use of multiparametrical test systems of lymphocyte activation based on FP, production of new immunologically active drugs by "high content screening" of biologically active compounds, which is essentially the applied realization of system biology, is especially urgent [70].

\section{СУЧАСНІ ФЛУОРЕСЦЕНТНІ МЕТОДИ ДОСЛІДЖЕННЯ МЕХАНІЗМІВ АКТИВАЦІї ЛІМФОЦИТІВ}

\author{
Г. А. Любченко ${ }^{1}$, Р. М. Морєв ${ }^{2}$, \\ Л. С. Холодна \\ ${ }^{1}$ Київський національний університет \\ імені Тараса Шевченка, Україна; \\ ${ }^{2}$ Інститут фізіології ім. О. О. Богомольця \\ НАН України, Київ; \\ e-mail: gannalb@yahoo.com
}

Флуоресцентні протеїни $€$ найперспективнішими інструментами для вивчення сигнальних процесів у лімфоцитах. Цей короткий огляд підсумовує нові досягнення в отриманні зображень на основі методів флуоресценції, що розвивалися останніми роками, також обговорюються нові технологічні та методологічні досягнення, такі як люмінесцентні фотоперемикачі, відновлення флуоресценції після фотознебарвлення (FRAP), перенесення енергії за допомогою флуоресцентного резонансу (FRET), флуоресцентна мікроскопія зображення тривалості життя (FLIM), фотоактивована локалізаційна мікроскопія (PALM), стохастична оптична мікроскопія реконструкції (STORM), стимульоване виснаження, індуковане випромінюванням (STED), повне внутрішнє відбиття флуоресценції (TIRF) та інші методики. Цей огляд також висвітлює останні досягнення в області аналізу зображень живих тканин in vitro, нові застосування проточної цитофлуориметрії із використанням генетично кодованих флуоресцентних протеїнів і перспективи для розвитку нових імунологічних тест-систем на основі технології флуоресцентних протеїнів, сучасні прикладні підходи до використання проточної цитометрії 3 генетично кодованими флуоресцентними протеїнами, а також перспективи розвитку нових імунологічних тест-систем на основі технології флуоресцентних протеїнів.

К л ю ч о в і с л о в а: активація лімфоцитів, тест-системи, флуоресцентні протеїни, флуоресцентні методи.

\section{СОВРЕМЕННЫЕ ФЛУОРЕСЦЕНТНЫЕ МЕТОДЫ ИССЛЕДОВАНИЯ МЕХАНИЗМОВ АКТИВАЦИИ ЛИМФОЦИТОВ}

\author{
Г. А. Любченко ${ }^{1}$, Р. М. Морев $^{2}$, \\ Л. С. Холодная ${ }^{1}$
}

${ }^{1}$ Киевский национальный университет имени Тараса Шевченко, Украина;

${ }^{2}$ Институт физиологии им. А. А. Богомольца НАН Украины, Киев; e-mail: gannalb@yahoo.com

Флуоресцентные протеины являются самыми перспективными инструментами для изучения сигнальных процессов в лимфоцитах. Этот краткий обзор подытоживает новые достижения в получении изображений на основе методов флуоресценции, которые разрабатывались в последние годы, также обсуждаются новые технологические и методологические достижения, такие как люминисцентные фотопереключатели, возобновление флуоресценции после фотообесцвечивания (FRAP), перенесение энергии с помощью флуоресцентного резонанса (FRET), флуоресцентная микроскопия изображения продолжительности жизни (FLIM), фотоактивированная локализационная микроскопия (PALM), стохастическая оптическая микроскопия реконструкции (STORM), стимулированное истощение, индуцированное излучением (STED), полное внутреннее отражение флуоресценции (TIRF) и другие методики. Этот обзор также освещает последние достижения в области анализа изображений живых тканей, полученных in vitro, новые применения проточной цитофлуориметрии с использованием генетически кодированных флуоресцентных протеинов и перспективы для развития новых иммунологических тест-систем на основе технологии флуоресцентных протеинов, современные прикладные подходы к использованию проточной цитометрии с генетически кодированными флуоресцентными 
протеинами, а также перспективы развития новых иммунологических тест-систем на основе технологии флуоресцентных протеинов.

К л юче вы е с лов а: активация лимфоцитов, тест-системы, флуоресцентные протеины, флуоресцентные методы.

\section{References}

1. Day R., Schaufele F. Fluorescent protein tools for studying protein dynamics in living cells: a review. J. Biom. Opt. 2008;13(3):031202.

2. Changa H., Zhanga M., Jia W., Chend J., Zhange Y., Liue B. A unique series of reversibly switchable fluorescent proteins with beneficial properties for various applications. Proc. Natl. Acad. Sci. USA Early Edition. 2012:1-6.

3. Goedhart J., Stetten D., Noirclerc-Savoye M., Lelimousin M., Joosen L., Hink M. Structureguided evolution of cyan fluorescent proteins towards a quantum yield of $93 \%$ : [electronic resource]. Nat. Commun. 2012;3(751):1-9.

4. Subach F. V., Zhang L., Gadella T. W., Gurskaya N. G., Lukyanov K. A., Verkhusha V. V. Red Fluorescent Protein with Reversibly Photoswitchable Absorbance for Photochromic FRET. Chem. Biol. 2010;17(7):745-755.

5. Mustelinand T., Tasken K. Positive and negative regulation of T-cell activation through kinases and phosphatases. Biochem. J. 2003;371:15-27.

6. Liubchenko G. A., Appleberry H. C., Holers V. M., Banda N. K., Willis V. C., Lyubchenko T. Potentially autoreactive naturally occurring transitional T3 B lymphocytes exhibit a unique signaling profile. J. Autoimmun. 2012;38(4):293-303.

7. Rincon M. MAP-kinase signaling pathways in $\mathrm{T}$ cells. Curr. Opin. Immun. 2001;13:339-345.

8. Kane L. P., Lin J., Weiss A. Signal transduction by the TCR for antigen. Curr. Opin. Immun. 2000;12:242-249.

9. Weiss L., Whitmarsh A. J., Yang D. D. Regulation of c-Jun NH2-terminal Kinase (Jnk) Gene Expression during $\mathrm{T}$ Cell Activation. J. Exp. Med. 2000;191(1):139-146 .

10. Lyubchenko T., Nielsen J. P., Miller S. M., Liubchenko G. A., Holers V. M. Role of initial protein phosphorylation events and localized release-activated calcium influx in B cell antigen receptor signaling. J. Leukoc. Biol. 2009;85(2):298-309.
11. Kholodna L. S., Gordienko V. M., Liubchenko T. A. Morphofunktional properties of lymphoid organs of mice After immunization with staphilococcal antigens. Bullet. Modern Med. 1995:46-49.

12. Afonin S. E., Davydovska T. A., Shaturskiy O. Y. Shuba M. F., Kholodna L. S. Study of membrane activity of staphylococcus protein A on bimolecular lipid membranes. Bullet. Taras Shevchenko Nat. Univ. Kyiv. 1996;(3-4):30-36.

13. Oleshko G. M., Liubchenko G. A. Biochemical components and immunobiological activity of factors of staphylococci pathogenicity. Ukr. Biokhim. Zhurn. 2006;78(1):20-28.

14. Oleshko G. M., Liubchenko G. A. Immunobiological properties of surface proteinsadhesines of staphylococcus. Ukr. Biokhim. Zhurn. 2007;79(3):5-12.

15. Bogdanova O. B., Oleshko G. M., Morgaienko O. O., Liubchenko G. A., Kholodna L. S., Ostapchenko L. I. Influence of ionizing radiation on activation of tyrosine phosphatase activity in lymphoid cells After preincubation with cellbound protein A. Phys. Liv. 2005;13(1):86-90.

16. Gagnon J., Ramanathans., Leblanc C., Cloutier A., McDonald P. P., Ilangumaran S. IL-6, in synergy with IL-7 or IL-15, stimulates TCR-independent proliferation and functional differentiation of $\mathrm{CD}^{+} \mathrm{T}$ lymphocytes. J. Immunol. 2008;180:7958-7968 .

17. Jorge C., Christopher A., Hunter N. F. KB Family of transcription factors: central regulators of innateand. Adapt. Imm. Funct. Clin. Microb. Rev. 2002;15(3):414-429.

18. Shuai K., Liu B. Regulation of JAK-STAT signalling in the immune system. Nat. Rev. Immunol. 2003;3(11)900-911.

19. Ryazantseva N. V., Novitskii V. V., Zhukova O. B., Biktasova A. K., Chechina O. E., Sazonova E. V. Role of NF-kB, p53, and p21 in the regulation of TNF- $\alpha$ mediated apoptosis of lymphocytes. Bullet. Exp. Biol. Med. 2010;149(1):50-53.

20. Macian F. NFAT proteins: key regulators of T-cell development and function. Nat. Rev. Immunol. 2005;5(6):472-484.

21. Stepanenko O. V., Kuznetsova I. M., Kuznetsova I. M. Denaturation of proteins with beta-barrel topology induced by guanidine hydrochloride. Spectrosc. International J. 2010;24:367-373. 
22. Maino V. C., Suni M. A., Ruitenberg J. J., SmithMcCollum R. M. 1995. FastImmune Assay System. A rapid and comprehensive system for assessinglymphocyte function by flow cytometry. Becton Dickinson, Immunocytometry Systems, 1995. 7 p.

23. Liubchenko G. A., Ostapchenko L. I. Immunobiological signaling in response to $S$. aureus Extracellular adherence protein (Eap). $J$. Immunol. (Meeting Abstract Supplement). 2010;184(40):27.

24. Gascoigne N. R. J., Ampudia J., Clamme J. P., Fu G., Lotz C., Mallaun M., Niederberger N., Palmer E., Rybakin V., Yachi P. P., Zal T. Visualizing intermolecular interactions in $\mathrm{T}$ cells. Curr. Top. Microbiol. Immunol. 2009;334:31-46.

25. Piatkevich K., Verkhusha V. Guide to red fluorescent proteins and biosensors for flow cytometry. Methods Cell Biol. 2011;102:431-461.

26. Balagopalan L., Sherman E., Barr V., Samelson L. Imaging techniques for assaying lymphocyte activation in action. Nat. Rev. Immunol. 2011;11(1):21-33.

27. Liubchenko G., Appleberry H., Striebich C ., Franklin K., Derber L., Holers V., Lyubchenko T. Rheumatoid arthritis is associated with signaling alterations in naturally occurring auto reactive B-lymphocytes. J. Autoimmunity. 2013;40:111121.

28. Kaizuka Y., Douglass A., Varma R., Dustin M., Vale R. Mechanisms for segregating $\mathrm{T}$ cell receptor and adhesion molecules during immunological synapse formation in Jurkat T cells. Proc. Natl. Acad. Sci. USA. 2007;104:20296-20301

29. Kress A., Ferrand P., Rigneault H., Trombik T., He H., Marguet D. Probing orientational behavior of MHC class I protein and lipid probes in cell membranes by fluorescence polarizationresolved Imaging. Biophys. J. 2011;101(2):468476.

30. Zhong H. Photoactivated localization microscopy (PALM): an optical technique for achieving 10-nm resolution adapted from imaging: a laboratory manual. Cold Spring Harb Protoc, 2010. 91 p.

31. Rego E. H., Shao L., Macklin J. J., Winoto L., Johanssond G. A., Kamps-Hughes N., Davidson M. W., Gustafsson M. G. Nonlinear structured-illumination microscopy with a photoswitchable protein reveals cellular structures at 50-nm resolution. Proc. Natl. Acad. Sci. USA. 2012;109:135-143.

32. Brown A., Hategan A., Safer D., Goldman Y., Discher D. Cross-correlated TIRF/FPM reveals asymmetric distribution of forcegenerating heads along self-assembled "synthetic" myosin filaments. Bioph. J. 2009;96:1952-1960.

33. Williamson D. J., Owen D. M., Rossy J., Magenau A., Wehrmann M., Gooding J. J. Pre-existing clusters of the adaptor Lat do not participate in early T cell signaling events. Nat. Immunol. 2011;12(7):655-662.

34. Subach F. V., Patterson G. H., Renz M., Lippincott-Schwartz J., Verkhusha V. V., Verkhusha V. Bright monomeric photoactivatable red fluorescent protein for two-color superresolution sptPALM of live cells. J. Amer. Chem. Soc. 2010;132(18):6481-6491 .

35. Stepanenko O. V., Stepanenko O. V., Shcherbakova D. M., Kuznetsova I. M., Turoverov K. K., Verkhusha V. V. Modern fluorescent proteins: from chromophore formation to novel intracellular applications. Biotechniques. 2011;51(5):313-314.

36. Coelho M., Maghellia N. Tolić-Nørrelykke I. M. Single-molecule imaging in vivo: the dancing building blocks of the cell. Integr. Biol. 2013;5:748-758.

37. Beltman J. B., Marée F. P. M., Lynch J. N., Miller M. J., de Boer R. J. Lymph node topology dictates T cell migration behavior. J. Exp. Med. 2007;204(4):771-780.

38. Brown A., Oddos S., Dobbie I., Alakoskela J., Parton R., Eissmann P. Remodelling of cortical actin where lytic granules dock at natural killer cell immune synapses revealed by super-resolution microscopy. PLoS Biol. 2011;9(9):e1001152.

39. Torres A., Wu M., Holowka D., Baird B. Nanobiotechnology and cell biology: micro-and nanofabricated surfaces to investigate receptormediated signaling. Annu. Rev. Biophys. 2008;37:265-288.

40. Hsu C., Hsieh W., Waldman A., Clarke F., Huseby E., Burkhardt J. Ligand mobility modulates immunological synapse formation and T cell activation. PLoS ONE. 2012;7(2):e32398.

41. Piatkevich K., Malashkevich V., Almo S., Verkhusha V. Engineering ESPT pathways based on structural analysis of LSS mKate red 
fluorescent proteins with large Stokes shift. J. Am. Chem. Soc. 2010;132:10762-10770 .

42. Subach F., Zhang L., Gadella T., Gurskaya N., Lukyanov K., Verkhusha V. Red fluorescent protein with reversibly photoswitchable absorbance for photochromic FRET. Chem. Biol. (Cellpress). 2010;17:745-755.

43. Morozova K., Piatkevich K., Gould T., Zhang J., Bewersdorf J., Verkhusha V. Far-Red fluorescent protein excitable with red lasers for flow cytometry and super-resolution STED nanoscopy. Biophys. J. 2010;99:13-15.

44. Wu B., Piatkevich K., Lionnet T., Singer R., Verkhusha V. Modern fluorescent proteins and imaging technologies to study gene expression, nuclear localization, and dynamics. Curr. Opin. Cell Biol. 2011;23:310-317.

45. Michael J., Kubes P. Intravascular immunity: the host-pathogenen counter in blood vessels. Nat. Rev. Immunol. 2009;9:364-365.

46. Shcherbakova D. M., Subach O. M., Verkhusha V. V. Red fluorescent proteins: advanced imaging applications and future design. Angew. Chem. Int. Ed. 2012;51(43):10724-10738.

47. Kawano H., Kogure T., Abe Y., Mizuno H., Miyawaki A. Two-photon dual-color imaging using fluorescent proteins. Nat. Methods. 2008;5(5):373-374.

48. Huppa J., Davis MT-cell-antigen recognition and the immunological synapse. Nat. Rev. Immunol. 2003;3:973-983.

49. Gunewardene M. S., Subach F. V., Gould T. J., Penoncello G. P., Gudheti M. V., Verkhusha V. V., Hess S. T. Superresolution imaging of multiple fluorescent proteins with highly overlapping emission spectra in living cells. Biophys. J. 2011;101(6):1522-1528.

50. Bousso P., Bhakta N., Lewis R., Robey E. Dynamics of thymocyte-stromal cell interactions visualized by two-photon microscopy. Science. 296:1876-1880.

51. Schaer D. A., Li Y., Merghoub T., Rizzuto G. A., Shemesh A., Cohen A. D. Detection of intratumor self antigen recognition during melanoma tumor progression in mice using advanced multimode confocal/two photon microscope. PLoS One. 2011;6(6):e21214.

52. Morozova K., Piatkevich K., Gould T., Zhang J., Bewersdorf J., Verkhusha V. Far-red fluorescent protein excitable with red lasers for flow cytometry and superresolution STED nanoscopy. Biophys. J. 2010;99(2):13-15.
53. Yoshizaki H., Mochizuki N., Gotoh Y., Matsuda M. Akt-PDK1 Complex mediates epidermal growth factor-induced membrane protrusion through Ral activation. Mol. Biol. Cell. 2007;18:119-128 .

54. Schmid J., Birbach A. Fluorescent proteins and fluorescence resonance energy transfer (FRET) as tools in signaling research. Thromb. Haemost. 2007;97(3):329-500.

55. Gajendran N. Identifying activated $\mathrm{T}$ cells in reconstituted RAG deficient Mice using retrovirally transduced Pax 5 deficient pro-B cells. PLOS ONE. 2009;4(4):e5115.

56. Peacock R. W., Wang C. L. A genetic reporter system to gauge cell proliferation rate. Biotechnol. Bioeng. 2011;108(9):2003-2010.

57. Wang L., Carnegie G. K. Flow cytometric analysis of bimolecular fluorescence complementation: a high throughput quantitative method to study protein-protein interaction. J. Vis. Exp. 2013:78.

58. Ohmichi Y., Hirakawa J., Imai Y., Fukuda M., Kawashima H. Essential role of peripheral node addressin in lymphocyte homing to nasalassociated lymphoid tissues and allergic immune responses. J. Exp. Med. 2011;208(9):1015-1025.

59. Aoki K., Kiyokawa E., Nakamura T., Matsuda M. Visualization of growth signal transduction cascades in living cells with genetically encoded probes based on Forster resonance energy transfer. Phil. Trans. R. Soc. B. 2008;363:21432151.

60. Liubchenko G., Appleberry H., Striebich C., Franklin K., Derber L., Holers V. Rheumatoid arthritis is associated with signaling alterations in naturally occurring autoreactive B-lymphocytes. J. Autoimm. 2012:1-11.

61. Mues M., Bartholomäus I., Thestrup T., Griesbeck O., Wekerle H., Kawakami N. Realtime in vivo analysis of $\mathrm{T}$ cell activation in the central nervous system using a genetically encoded calcium indicator. Nat. Med. 2013;19(6):778-783.

62. Kriz A., Schmid K., Baumgartner N., Ziegler U., Berger I., Ballmer-Hofer K. A plasmid-based multigene expression system for mammalian cells. Nat. Commun. 2010;1:120.

63. Drobizhev M., Makarov N. S., Tillo S. E., Hughes T. E., Rebane A. Two-photon absorption properties of fluorescent proteins. Nat. Methods. 2011;8(5):393-399. 
64. Bückers J., Wildanger D., Vicidomini G., Kastrup L., Hell S. W. Simultaneous multilifetime multi-color STED imaging for colocalization analyses. Opt. Express. 2011;19(4):3130-3143.

65. Sobhy M. A., Elshenawy M. M., Takahashi M., Whitman B. H., Walter N. G. Versatile single-molecule multi-color excitation and detectionfluorescence setup for studying biomolecular dynamics. Rev. Sci. Instrum. 2011:82.

66. Wu B., Piatkevich K. D., Lionnet T., Singer R. H., Verkhusha V. V. Modern fluorescent proteins and imaging technologies to study gene expression, nuclear localization, and dynamics. Curr. Opin. Cell Biol. 2011;23(3):310-317.

67. Kawamoto T., Shimizu M. A method for preparing 2 -to 50 -micron-thick fresh-frozen sections of large samples and undecalcified hard tissues. Histochem. Cell Biol. 2000;113(5):331339.

68. Walch A., Rauser S., Deininger S.-O., Höfler H. MALDI imaging mass spectrometry for direct tissue analysis: a new frontier for molecular histology. Histochem. Cell Biol. 2008;130(3):421434.

69. Balagopalan L., Sherman E., Barr V. A., Samelson L. E. Imaging techniques for assaying lymphocyte activation in action. Nat. Rev. Immunol. 2011;11(1):21-33.

70. Freeley M., Bakos G., Davies A., Kelleher D., Long A., Dunican D. J. A high-content analysis toolbox permits dissection of diverse signaling pathways for $\mathrm{T}$ lymphocyte polarization. J. Biomol. Screen. 2010;15(5):541-555.

Received 28.03.2014 